\title{
Carving out a new market niche: Historic world of wines
}

\author{
Vahe Keushguerian and Irina Ghaplanyan \\ Semina Consulting, Melkumov 18/8, Yerevan 0054, Armenia
}

\begin{abstract}
When in 2007 teams of archaeologists discovered the oldest known winery in a cave in Areni - a wine region of Armenia - Armenian winemaking was in a nascent stage. Arguably this significant historic discovery gave a much-needed boost to Armenian winemaking - as now the country's wine producers could tell a compelling story. This discovery also drew greater attention of other scientists - from grape geneticists to archaeobotanics - to continue the research and inquiry into indigenous vinifera grape varietals of Armenia, and how these species could potentially be linked to European grapes. Most notably, these historic varieties, although some entirely extinct, others nearly extinct, but many have exceptional vinifera qualities. This, in turn, continues to engage more and more not only local winemakers but now also renowned and prominent names in the world of wine. The increasingly high quality wines coming out of not only Armenia, but also other countries from the geographic region, which this paper suggest to qualify as historic, deserve not only a mention, but arguably a niche of their own.
\end{abstract}

\section{Introduction}

This paper addresses the need for creating a new niche in the global wine market. What a number of authors previously suggested calling a "Third World" or the "In-Between" world, this paper suggests dubbing as Historic World [1]. Contemporary wine geography omits a number of countries, which have either been historically producing wines but for geographic or political reasons have not been marked on the global wine map; or have had millennial past history of winemaking but have not resumed the viticultural traditions until recently.

In proposing the term Historic World this paper suggests three various markers or identifiers, which would differentiate or map out countries that potentially fall within this proposed categorization. The first and most prominent marker is time. As this section will detail below, there is an almost four millennial gap between the first evidence of organized and ritualized winemaking and the winemaking evidence that we find in the Old World. In proposing to mark or identify countries, which fall within the category of Historic World, the paper argues that evidence of earliest winemaking should serve as the most definitive identifier. It then cites various sources suggesting earliest winemaking practices and identifies the 'cut-off' point for Historic World - much like the time identifier used in deciphering Old World from the New World.

The second identifier, which flows from and is largely defined by the previous one (time) is the marker of space or geography of viticultural history. If the geography of the New World is sporadic, as winemaking migrated with people, as they travelled across continents, the geography of the Old World is continuous - present in one continent. The space of the Historic World is largely defined by the evidence of historic winemaking, which is being discovered on a continuous basis. However, as the paper will further detail, there is already an identifiable geographic locale of historic winemaking, spanning two continents from Armenia to Egypt, with the most ancient evidence situated in the heart of that belt - the Caucasus or Transcaucasia.

The third identifier of the Historic World is the indigenous grape varietals. The New World cultivates varietals brought from the Old World. Whereas cultivars of the Old World are migrants in their turn - as recent genetic evidence shows. What is remarkable about the Historic World or at least some of the countries where the genetic as well as archeological research is underway - the indigenous varietals present in those spaces have been cultivated for millennia.

Lastly, the paper addresses the marketing benefits of positioning wines that come out of these countries in this new market niche. The benefits for both the producers who are able to position their wines in a different category, and compete within it; and for consumers, who would have better advantage in "navigating" and finding these wines.

\section{Historic world: Defining the time}

The origins of winemaking date back to Neolithic times yet the world of wine today is defined by Old and New.

The geography of the New World of wine as well as time identification are sporadic as they are defined by when and how humans migrated, took with them the grape vine and began cultivating it in a given location. The pattern and development of viniculture in the New World were mostly defined by the political and military conquests, economic development and suitable climatic conditions for the imported vine. But modern agricultural technology and science have lately removed the barrier of climatic conditions and the recent "additions" to the New World of wine are countries of so called tropical viticulture, which do not even fall within the known viticultural belts below and above the equator. The list has been expanded to include 
Vietnam, Brazil, China and India. Hence, viticulture today spans five continents and with the emerging global warming many scholars have theorized various development patterns both for the vinifera vines as well as the climatic conditions.

So on the one hand, the New World is defined by geography - i.e. any wine producing country outside of the known European Old World is considered New, yet time remains a subject of debate. If the recent "members" of the New World have joined the category within the past ten years, the "oldest" dweller of this category fights for the recognition of being an Old producer. South Africa began its vinicultural history 350 years ago and some of the vineyard estates have been in family hands for six or seven generations - longer than most Old World vineyards and far longer than anything you will find in California [2].

The Old World is also defined by geography and time factors, however both the boundaries of the Old World and the time to which the origins of this category are attributed are still contested. Should modern day Greece (Ancient Greece) or Italy (Ancient Rome) be considered as part of the Old World or the Historic World? Most of the scholars agree on a period around first millennium BC, and more specifically as early as 800 to $700 \mathrm{BC}$ on the first evidence of winemaking in this part of the world.

The cultivation and domestication of the grapevine appears to have occurred between the seventh and the fourth millennia BC, in a geographical area between the Black Sea and Iran [3]. The grapevine was then spread by humans into Europe starting from the easternmost Mediterranean areas. In Greece and Crete, the beginnings of viticulture would have started during the fifth millennium BC [4]. Given this evidence, provided by Valamoti et al. Greece should be considered as part of the Historic World.

In Italy, the most ancient testimonies of grapevine cultivation date back to the ninth century BC [5], which along with Spain (arguably) makes Italy the earliest country for winemaking in the Old World.

Estreicher argues that it is well established that, almost 3000 years ago, the Phoenicians brought vine cuttings and knowledge of viticulture and winemaking to Southern Spain. However, it is not known if the local population cultivated grapes before that time. A decorated fourth century BC clay drinking cup was found in a tomb in the Ribera del Duero region. This is before any Roman influence. This is also far away from the coast and from direct Phoenician influence. The chemical analysis of the residue in the cup proves that it did contain wine [6].

Another interesting evidence has been found in modern day Austria. Around $700 \mathrm{BC}$, the Celts and most probably their Illyrian predecessors began to cultivate the vine in a primitive form and vitis vinifera grape pips dating from the Hallstatt cultural period, were discovered in former Celtic dwellings in the wine-producing village of Zagersdorf in Burgenland [7].

Lastly, it is currently believed that the emergence of viticulture in France was concomitant with the foundation of Marseille (600 BC) by the Greek Phocaeans [8].

Given all these various sources and evidence that grapevine domestication and cultivation in Europe began around first millennium $\mathrm{BC}$, it is important to note that there is an almost four millennial gap from when the first evidence of viniculture has been found in Greece and when the first evidence of wine has been found westwards towards Italy, France and Spain.

Much is already known about the initial domestication of the Eurasian grapevine (Vitis vinifera) and the emergence of a "wine culture" in the mountainous Near East, as early as the Neolithic period. Less is known about how viniculture moved from east to west across the Mediterranean Sea, eventually reaching Italy and France. Merchant seafarers, including Canaanites and later Phoenicians and Greeks, were the principal conveyors, who progressively established colonies along the coasts and on one island after another [9].

Given this vast gap as well as early evidence of vine cultivation in Ancient Greece, the latter should fall under the category of the Historic World.

Largest and most detailed evidence of ancient wine making comes from Egypt, where wine jars were placed in the Egyptian tombs as funerary offerings since the Predynastic Period (4000-3100 BC). During the New Kingdom Period (1539-1075 BV), wine jars (amphorae) were inscribed in hieratic to indicate: the vintage year, the name of the product, the quality, the provenance, the property (royal or private) and the name and the title of the wine maker [10].

Another important center for ancient winemaking is modern day Israel, or more specifically the area of Upper Galilee, where according to Koh et al., viticulture dates back to the Early Bronze Age IB period (ca. 3100 BC) [11].

The oldest archaeological evidence of ancient winemaking comes from Hajji Firuz Tepe - a Neolithic site in Northwestern Iran dated 5000-5400 BC. The shape of the grape pips found at the site proves that hermaphrodite (cultivated) vines were used. The oldest known winemaking setup is in Southern Armenia at a site called Areni-1, not very far north of Hajji Firuz Tepe. It is dated 4100 BC. The winemaking involved crushing clusters of grape, probably by foot. The juice would flow into buried clay jars for fermentation. Here again, the shape of the pips provides evidence of wine cultivation [12].

What is noteworthy about the findings in the Areni-1 site is that in a Late Chalcolithic cave dating back to 4223-3790 BC an organized and complete wine production was in place [13].

All the cited scholarly finds and arguments prove that there is an almost four millennial gap between the first evidence of grape vine domestication and cultivation and winemaking evidence in modern day Europe or Old World of wine. Building on these finds and arguments, this paper suggests identifying the time period for the Historic World to be dated from sixth millennium to the first millennium BC.

\section{Historic world: Defining the space}

With the identification and suggestion of the timeframe for the Historic World, the space identification becomes a simpler task.

As cited above, the earliest evidence of grapevine domestication occurred around sixth millennium BC in the Near East, or more specifically in what is known today as Transcaucasia. Archaeologically and chemically 
confirmed evidence of winemaking found in Armenia and modern day Iran, as well as emerging evidence of ancient winemaking in Georgia (in Shulaveri-Shomu area), place this region into the heart of the geographic span of the historic world of wine [14].

From this area, viticulture spreads to neighboring regions such as lower Mesopotamia (the "Fertile Crescent"), then the Nile delta and the eastern Mediterranean [15]. This space would encompass modern day Armenia, Georgia, Northern Iran, Western Armenia or Modern day Turkey, Syria, Lebanon, Israel, Palestine, Jordan, Egypt, Cyprus, Greece and Crete.

It is important to note that for political, cultural, military and religious reasons, not all the countries listed in this category produce wine today, which further reduces the list to - Armenia, Georgia, Turkey, Lebanon, Israel, Jordan, Egypt, Cyprus and Greece.

\section{Investigating indigenous varietals}

Before engaging in the discussion on the market demand and advantages of introducing this new niche into the world of wine, it is important to briefly discuss the significance of indigenous varietals coming out of the Historic World.

As archaeological and biomolecular evidence of winemaking points to the Near East, so does the genetic origin of vitis vinifera. According to Myles et al., the relatedness among geographically diverse sample of vinifera and sylvestris provides strong support for an origin of vinifera in the Near East: all vinifera populations are genetically closer to eastern sylvestris than to western sylvestris [16].

Vouillamoz et al., in investigating the origins of European grapes tested 116 accessions of traditional grape cultivars from Armenia, Georgia and Turkey, using 12 nuclear microsatellite markers. The results showed that each germplasm could have multiple origins and although they are now separated, they might have some common ancestors. In addition, four varieties from Western Europe included as outgroups turned out to be more related to Georgian cultivars than other germplasms, suggesting possible ancient origin in Georgia [17].

There is much research currently underway in various laboratories around the world aimed at further understanding the migration patterns of the grapevine, its evolution and its loss of genetic diversity once it occurred in Western Europe. A significant amount of research is also underway in the countries of the Historic World, where archaeologists, grape geneticists, bioinformaticians and other scientists are attempting to find more clues towards understanding the transition, evolution and genetic connection of indigenous vinifera cultivars to the vinifera varietals in Europe.

In Armenia, the Faculty of Biology at the Yerevan State University is conducting an extensive work under the guidance of Dr. Nelly Hovhannisyan, fingerprinting the indigenous varietals and creating a data bank for these varietals. The team of scientists is also engaged in fieldwork, trying to find indigenous varietals, largely believed to be extinct.

The same "wine hunt" was undertaken in Israel under the guidance of Dr. Elyashiv Drori at the Ariel University, who has undertaken extensive work aimed at finding indigenous Israeli varietals, believed to be extinct. In the course of three years Dr. Drori's team has found over 300 varietals of which 100 are unique to Israel and 10 are suitable for winemaking [18].

As more evidence continues to be unearthed on the origins of grapevine and winemaking in the Historic World, the countries of this region produce increasingly higher quality wines from indigenous varietals, bringing new flavors and new stories to the market. These wines and their origins deserve a market niche of their own.

\section{Market demand}

As discussed above, there are significant scientific reasons for identification of a new category within the geography of wine. In addition to these reasons this section will elaborate on marketing reasoning behind identification of this new niche as Historic World. The analysis is presented from the perspective of the producer, the consumer and the market at large.

Wine producers in the Historic World face a major challenge in attempting to position their products, as they do not fit either of the existing categories. As discussed, attempts have been made to brand them as wines of the third world, the emerging world, the world in-between and others. However, none of these were successful. Turkey attempted to brand its wine industry under the niche of the New Old world, however, that also proved unsuccessful. Suggestions have also been made to name this niche as Ancient World, however, ancient connotes something deceased or non-existent anymore, whereas Historic is continuous and living.

If proven successful and given the needed marketing space, producers in the Historic World will be more driven to work with indigenous varietals as opposed to European varietals. What originally began and was dubbed as "wine purism" is a leading trend today, where the market increasingly demands wines true to their locale - not only expressing the terroir but also the unique varietal. This in turn will lead to increased research, preservation and propagation of these indigenous varietals.

Positioning their wines in a separate category will give the producers of the Historic World the opportunity to have their own platform, where they can showcase the uniqueness of the history, of the terroir and grape varietals of their wines.

Global wine consumption in general and certain countries in particular have registered between low to average increase following the recovery after the global financial crisis [19]. Another noteworthy trend is increased demand for new wine products [20]. This is very telling about the leading consumer trends in wine. Modern consumer, who is increasingly joined by the millenials, is progressively understanding wine and the wine industry. As the average consumer's palate is well acquainted to the "usual suspects" of the wine industry, it is curious to know more and is hungry for novelty. In search of new products and to understand them well, the consumer needs guidance. The wines from the producers of the Historic World can offer both the traditional and millennial consumer the novelty and the uniqueness that they are looking for.

With the modern technology available throughout the world, production of quality wine has become a more 
mechanized and standardized practice. This along with other reasons has led to increased saturation of the global wine market with good quality table dry wine of various price categories. However, what is increasingly proving to sell well irrespective of price category are novelties on the wine market and wines that tell a story [21]. The benefits of the wines originating from the Historic World are that the countless stories behind these wines are yet untold; and in fact are constantly being discovered as archeologists and anthropologists continue to unearth more evidence and interpret it.

\section{Conclusion}

The wines of the Historic World tell the story of how human species produced this beverage in organized and ritualized fashion from vinifera grapes and drank them more than six millennia ago will serve as yet another boost to the wider consumer interest and possible increase in wine consumption. What is particularly attractive in these stories is that evidence shows that this was not a spontaneous winemaking practice, but an organized and conscious process, where human communities gathered around the winemaking process to produce this drink and celebrate or ritualize an occasion. This fact alone makes wine one of the most spectacular drinks ever made by human species and provides yet another row of reasons to continue drinking and discovering the unlimited world of this beverage.

\section{References}

[1] G. Banks and J.Overton, Jrnl. of Wine Research 21, Iss. 1, p.57-75 (2010) http: / /www . tandfonline.com/doi/abs/10.1080/09571264. $2010.495854 \#$

[2] M. Veseth, The Wine Economist, October 9 (2012) http: //wineeconomist.com/2012/10/ 09/south-africa-old-world-or-new/

[3] J.F. Terral, E. Tabard, L. Bouvy, S. Ivorra, T. Pastor, I. Figueiral, S. Picq, J.-B. chevance, C. Jung, L. Fabre, C. Tardy, M. Compan, R. Bacilieri, T. Lacombe and P. This, Annals of Botany, Iss. 105, 3, p. 443 (2010)

[4] S.M. Valamoti SM, M. Mangafa, C. KoukouliChrysanthaki, D. Malamidou. Antiquity. 81, (2007) pp. 54-61 (as quoted in Terral et al)

[5] A. Di Vora, L. Castelletti, Rivista Archeologica dell'Antica Provincia e Diocesi di Como, 176, pp. 333-358 (1995) (As quoted in Terral et al)
[6] S.K. Estreicher, European Review, 21, Iss. 02, (2013), p. 209-210

[7] Austrian wine: http://www.austrianwine. com/our-wine/a-taste-of-culture-a - special-treat/historyl

[8] Brun JP, Laubenheimer F. La viticulture en Gaule. Gallia. 2001;58:203-219 (As quoted in Terral et al)

[9] P.E. McGovern, B.P. Luley, N.Rovira, A. Mirzoian, M.P. Callahan, K.E. Smith, G.R.Hall, T.Davidson and J.M. Henkin, Proceedings of the Natnl. Acad. of Sciences USA, Iss. 25, 110, (2013), p.10147-10148.

[10] M.R. Guasch-Jane, S. Fonseca, M. Ibrahim, ISPRS Annals of the Photogrammetry, Remote Sensing and Spatial Information Sciences, II-5/W1, (2013)

[11] A.J. Koh, A. Yasur-Landau, E.H. Cline, Plos One, 9, Iss. 8, (2014), p.1

[12] S.K. Estreicher, "A Brief History of Wine in Spain," European Review, 21, Iss. 02, May, 2013; p.209-2010

[13] H.Barnard, A.N.Dooley, G.Areshian, B.Gasparyan and K.F.Faull, Journal of Archaeological Science, 38, Iss. 5, (2010), pp.97-984

[14] P.Salopek, "Ghost of the Vine," April 14 (2015) National Geographic: http://outofedenwalk. nationalgeographic. com/2015/04/14/ghost-of - the-vine/

[15] A.F. Adam-Blondon, J.M. Martinez-Zapater, C.Kole, Genetics, Genomics and Breeding of Grapes, Taylor and Francis Group, FL, (2012), p. 9

[16] S. Myles, A.R. Boyko, C.L.Owens, P.J. Brown, F. Grassi, M.K.Aradhya, B. Prins, A.Reynolds, J.M. Chia, D.Ware, C.D. Bustamante and E.S. Buckler, PNAS, 108, Iss. 9 (2011)

[17] J.F. Vouillamoz, P.E. McGovern, A. Ergul, G. Soylemezoglu, G. Tevzadze, C.P. Meredith and M.S. Grando, Plant Genetic Resources 4, Iss. 2, pp. 144-158, (2006)

[18] S. Mustacich, "Looking for King David's Favorite Wine Grape," October 23 (2014): http: / / www . winespectator.com/webfeature/show/ id/50748

[19] OIV (Organisation Internationale de la Vigne et du Vin), Report, State of the Viniviticulture WorldMarket, May 2014: www.oiv.int/oiv/files/0\%20 ..../EN/OIV_Note_Conj_2014_־20EN. pdf

[20] Ibid

[21] Ibid. 